Marwah: Jurnal Perempuan, Agama dan Jender (p-ISSN: 1412-6095 | e-ISSN: 2407-1587)

Vol. 17, No. 1, 2018, Hal. 20 - 31

\title{
GAMBARAN KONSEP DIRI DAN ATTACHMENT IBU PADA ANAK KASUS NARKOBA
}

\author{
VIVIK SHOFIAH
}

UIN Sultan Syarif Kasim Riau, Indonesia vivik.shofiah@uin-suska.ac.id

\begin{abstract}
Self-concept is an element that influences individual behavior, positive self-concept will lead individuals to good behavior, and vice versa, negative self-concept can bring individuals to unwanted behavior. This study aims to see the description of children's self-concept with drug cases and how attachment to the mother. The research method in this study is descriptive qualitative by collecting data using interviews and observations. The subject of this study were five children with drug cases at Pekanbaru Special Class II Child Development Institution. The results showed that self-concept in children with drug cases was negative and attachment (attachment) to the mother was less safe, meaning that the quality of the affective relationship between children in the mother was less profound.
\end{abstract}

Keywords: self-concept, attachment, drugs

\section{ABSTRAK}

Konsep diri adalab elemen yang memberi pengaruh terhadap tingkab laku individu, konsep diri yang positif akan mengantarkan individu kepada perilaku yang baik, begitu juga sebaliknya, konsep diri yang negatif dapat membawa individu kepada perilaku yang tidak diinginkan. Penelitian ini bertujuan untuk. melihat gambaran konsep diri anak dengan kasus narkoba dan bagaimana kelekatan pada ibu. Metode penelitian dalam penelitian ini adalah kualitatif deskriptif dengan pengumpulan data menggunakan wawancara dan observasi. Subjek penelitian ini sebanyak lima anak dengan kasus narkoba di Lembaga Pembinaan Khusus Anak. Kelas II Pekanbaru. Hasil penelitian menunjukekan babwa konsep diri pada anak dengan kasus narkoba adalah negatif dan attachment (kelekatan) pada ibu termasuk kurang aman, artinya kualitas hubungan afeksi antara anak, pada ibu kurang mendalam.

Kata Kunci: konsep diri, attachment (kelekatan), narkoba

\section{A. PENDAHULUAN}

Indonesia adalah Negara yang berlandaskan hukum, pedoman ini tertuang dalam pasal 1 ayat 3 UUD 1945. Hal ini dapat dipahami sebagai suatu konsep bahwa Negara Indonesia menjalankan fungsi sesuai dengan ketentuan hukum yang berlaku. Sebagai Negara hukum, dapat diartikan bahwa barang siapa yang berada di wilayah Republik Indonesia yang melanggar peraturan atau norma-norma hukum yang berlaku akan mendapatkan sanksi dari Pemerintah. Sanksi yang dimaksudkan di sini adalah berupa hukuman atas perbuatan pelanggaran yang dilakukan sesuai dengan perbuatannya 
tersebut. Seseorang yang melanggar hukum akan diadili terlebih dahulu melalui sidang di Pengadilan Negeri, setelah terbukti bersalah baru ia dimasukkan ke Rumah Penjara atau lebih dikenal dengan Lembaga Pemasyarakatan (Yuliza, 2013).

Para penghuni Lembaga Pemasyarakatan tidak hanya orang-orang dewasa yang melakukan tindakan melanggar hukum. Anak-anak di bawah umur juga banyak yang menjadi penghuni Lembaga Pembinaan Khusus Anak (LPKA) karena melakukan perbuatan-perbuatan terlarang secara hukum. Menurut Yuliza (2013), banyak faktor yang melatar belakangi seorang anak melakukan pelanggaran hukum, salah satunya disebabkan karena anak masih dalam pertumbuhan sikap dan mental yang belum stabil atau proses penemuan jati diri serta dipengaruhi faktor pergaulan di lingkungan masyarakat.

Salah satu tindak pelanggaran hukum yang dapat mengirim seorang anak ke LPKA adalah penyalahgunaan narkoba. Menurut Lembaga Bantuan Hukum dan Advokasi Kebijakan Publik, sekurangnya ada 10 kasus pelanggaran hukum yang dilakukan oleh anak-anak dalam setiap pekannya yang mereka tangani, dan sebagian besarnya adalah penyalahgunaan narkoba. Bahkan, menurut Badan Narkotika Nasional (BNN), di daerah Lhokseumawe, Aceh, telah terdapat komunitas-komunitas narkoba yang melibatkan anakanak di bawah umur (Kompas, diakses pada tanggal 3 Maret 2016).

Di Pekanbaru, kasus yang berkaitan dengan narkoba juga melibatkan anak-anak di bawah umur. Pada tahun 2016, kasus penggunaan narkoba di provinsi Riau sendiri meningkat $20.38 \%$ dari tahun sebelumnya. Salah satu sebab peningkatan tersebut adalah keuntungan dalam bisnis jual-beli narkoba. Menurut penuturan AT, salah seorang tersangka kasus penjualan dan penggunaan narkoba, jutaan rupiah dapat ia peroleh hanya dalam satu minggu. AT sendiri mengungkapkan bahwa pengguna dan kurir narkoba banyak yang berasal dari anak-anak di bawah umur (Tribun, diakses pada tanggal 1 Oktober 2017).

Berdasarkan hasil interviu terhadap subjek berinisial F pada tanggal 23 Maret 2016 di Lembaga Pembinaan Khusus Anak (LPKA) Klas II Pekanbaru, peneliti mendapati salah seorang anak berusia 18 tahun yang tersangkut kasus narkoba. F mengakui bahwa awal mula dirinya menggunakan narkoba adalah karena pengaruh teman-teman serta ayahnya yang juga menggunakan narkoba. Selain itu, menurut penuturan F, beberapa anak yang masuk ke dalam LPKA diakibatkan keterlibatan dalam transaksi jual beli narkoba. Mereka melakukannya karena alasan ekonomi. Selama di LPKA, F mengaku menyesal akan semua perbuatannya, dan ingin memulai hidup yang baru setelah keluar dari LPKA. 
Anak-anak yang melakukan tindakan penyalahgunaan narkoba diamankan oleh pihak kepolisian atau BNN, setelah itu akan melalui berbagai proses pemeriksaan di pengadilan dan menerima hasil putusan pengadilan yang memungkinkan anak mendapat putusan pidana, sehingga akan menjalani masa pidana di Lembaga Pembinaan Khusus Anak (LPKA). Mereka akan dituntun untuk menjadi pribadi baru yang diharapkan jauh lebih baik dari sebelumnya. Hal ini sesuai dengan fungsi lapas yang dikemukakan oleh Dwiatmodjo (2013), yakni sebagai suatu lembaga pendidikan dan lembaga pembangunan.

Sesuai dengan UU No. 11 Tahun 2012 tentang Peradilan Pidana Anak, anak-anak yang berkonflik dengan hukum hanya akan menjalani masa pidana di LPKA sebagai upaya terakhir dalam waktu yang singkat dan dipisahkan dari orang dewasa. Dalam peradilan pidana anak, wajib untuk diupayakan diversi terlebih dahulu, yakni mengalihkan proses pengadilan pidana ke proses di luar peradilan pidana.

Irawan (2011), menyatakan bahwa penjahat (dewasa maupun anak-anak) akan dipandang negatif oleh masyarakat sehingga harus dikucilkan dari lingkungan, walaupun mereka telah menjalani pembinaan sedemikian rupa selama menjalani hukuman di LPKA. Sedangkan menurut Puspaningtyas (2011), kewajiban untuk mengembalikan kondisi para korban (narapidana anak) bukan hanya menjadi tanggung jawab pemerintah, tetapi juga merupakan tanggung jawab masyarakat pada umumnya. Anak dengan kasus narkoba juga dapat dicap sebagai anak yang sudah tidak bersih secara fisik dan mental sehingga akan membutuhkan masyarakat untuk kembali kepada dirinya yang sejati.

Firotussalamah (2016) menyatakan bahwa narapidana anak pada umumnya tidak memiliki kestabilan mental untuk menjalani kehidupan. Mereka cenderung hanya memikirkan kesenangan-kesenangan masa remaja sehingga memiliki potensi untuk mengulangi tindak pidana lagi setelah keluar dari LPKA. Hal ini mengindikasikan bahwa sebenarnya narapidana anak belum terlalu memahami konsep diri mereka. Shavelson (1981) mengemukakan bahwa konsep diri adalah persepsi seseorang terhadap dirinya sendiri, dan menurut Prasetyo (2013), konsep diri merupakan kerangka acuan (frame of reference) dalam berinteraksi dengan lingkungan. Pendapat ini dapat menjadi dasar bagi peneliti untuk memahami konsep diri pada narapidana anak kasus narkoba, bagaimana mereka dapat terjerumus kepada perbuatan terlarang dan bagaimana persepsi mereka terhadap diri mereka setelah menjadi narapidana.

Konsep diri adalah kerangka acuan seseorang dalam berperilaku, kerangka acuan tersebut haruslah terbentuk dengan sempurna sehingga seseorang dapat menjadi dirinya 
yang mengarah kepada perilaku positif. Menurut Irawan (2013), individu dengan konsep diri yang positif dapat berfungsi lebih efektif yang dapat dilihat dari kemampuan interpersonal, kemampuan intelektual dan penguasaan lingkungan. Narapidana anak kasus narkoba memiliki konsep diri, konsep diri yang mereka miliki tidak cukup untuk mencegah mereka masuk ke dalam lingkungan isolasi di LPKA. Memulai hidup yang baru di LPKA, berarti narapidana anak kasus narkoba akan menghadapi lingkungan yang baru pula, yang akan memberi warna baru terhadap cara mereka berperilaku.

Munculnya kasus kriminal dengan subjek maupun objek anak-anak memang perlu mendapatkan kajian khusus. Apa sebetulnya yang melatarbelakangi dan bagaimana dinamikanya. Bila kita bicara mengenai anak tentu saja kita berbicara mengenai kondisi anak itu sendiri, orang tua dan keluarga serta lingkungan. Keluarga sebagai unit terkecil dalam masyarakat memiliki tanggung jawab pertama untuk menjaga pertumbuhan dan perkembangan anak. Seorang anak akan mencapai pertumbuhan dan perkembangan optimal jika kebutuhan dasarnya terpenuhi, misalnya kebutuhan fisik (sandang, pangan, papan) dan kebutuhan psikologis berupa dukungan, perhatian dan kasih sayang. Namun ironisnya keluarga justru menjadi sumber ancaman dan ketidaktentraman anak, karena perlakuan salah yang sering diterima anak dari keluarga, khususnya orang tua. Hal ini sejalan dengan hasil penelitian yang didapatkan oleh Putra (dalam Andayani,2001) melalui penelitiannya "A Focused on Child Abuse in Six Selected Provinces in Indonesia",menemukan bahwa hasil-hasil perlakuan salah (maltreated) terhadap anak yang terjadi dalam ranah publik dan domestik ternyata sebagian besar dilakukan oleh orang tua mereka. Adapun yang dimaksud dengan perlakuan salah dalam hal ini adalah segala jenis bentuk perlakuan terhadap anak yang mengancam kesejahteraan anak untuk tumbuh dan berkembang secara optimal baik fisik, sosial, psikologis, mental dan spiritual (Irwanto dalam Andayani, 2001). Hubungan anak dengan orang tua merupakan sumber emosional dan kognitif bagi anak. Hubungan tersebut memberi kesempatan bagi anak untuk mengeksplorasi lingkungan maupun kehidupan sosial. Hubungan anak pada masamasa awal dapat menjadi model dalam hubungan-hubungan selanjutnya. Hubungan awal ini dimulai sejak anak terlahir ke dunia, bahkan sebetulnya sudah dimulai sejak janin berada dalam kandungan (Sutcliffe,2002). Klaus dan Kennel (dalam Bee, 1981) menyatakan bahwa masa kritis seorang bayi adalah 12 jam pertama setelah dilahirkan. Penelitian yang dilakukan menunjukkan bahwa kontak yang dilakukan ibu pada satu jam pertama setelah melahirkan selama 30 menit akan memberikan pengalaman mendasar 
pada anak. Hal senada juga dikemukakan oleh Sosa (dalam Hadiyanti,1992) bahwa ibu yang segera didekatkan pada bayi seusai melahirkan akan menunjukkan perhatian $50 \%$ lebih besar dibandingkan ibu-ibu yang tidak melakukannya.

Berdasarkan uraian di atas, maka peneliti tertarik untuk meneliti bagaimana gambaran konsep diri dan attachment ibu pada anak kasus narkoba di Lembaga Pembinaan Khusus Anak kelas II Pekanbaru.

\section{B. TINJAUAN PUSTAKA}

Menurut Papalia (2008), konsep diri adalah rasa akan diri sendiri; gambaran mental. Sedangkan menurut Burns (1979), proses pembentukan konsep diri adalah fase utama dan penentu yang utama dari setiap tingkah laku individu. Sedangkan Prasetyo (2013) menyatakan bahwa konsep diri dapat dibentuk melalui pandangan diri dan pengalaman yang positif. Individu dengan konsep diri yang positif dapat berfungsi lebih efektif yang dapat dilihat dari kemampuan interpersonal, kemampuan intelektual dan penguasaan lingkungan. Sedangkan konsep diri yang negatif dapat dilihat dari hubungan individu dan sosial yang terganggu.

Menurut Cooke, Baldwin, dan Howison (Irma dan Ramdhan, dalam Verawati, 2013), naparapidana menghadapi berbagai masalah, tidak hanya dari dalam lapas, tetapi juga dari luar lapas. Pada umumnya, permasalahan yang dihadapi oleh narapidana adalah kehilangan kebebasan fisik, kontrol atas hidup atau autonomi, keluarga, barang dan jasa, keamanan, kehilangan hubungan heteroseksual, maupun kurangnya stimulasi, dan gangguan psikologis, misalnya kecemasan, depresi, bunuh diri, menyakiti diri sendiri (selfinjury), dan membatasi diri untuk berkomunikasi. Selain itu, narapidana yang masih berusia belia akan memiliki masalah dalam hubungan sosial akibat stigma negatif yang ia terima dari masyarakat.

Anak didik pemasyarakatan yang terjerat kasus narkoba akan memiliki masalah dalam kehidupan. Masyarakat akan menilai mereka sebagai seseorang yang sudah tidak baik secara fisik dan mental, mereka akan menghadapi berbagai macam stigma yang melekat pada diri mereka. Semua itu, pada akhirnya akan menjadi pengalamanpengalaman yang akan memberikan pengaruh terhadap konsep diri mereka, sebagaimana yang dikemukakan oleh Papalia (2008), bahwa konsep diri adalah pemandu tindakan individu. 
Fitts (dalam Sutataminingsih, 2009) menyatakan bahwa konsep diri adalah sebagai suatu keseluruhan kesadaran atau persepsi mengenai diri yang diobservasi, dialami dan dinilai oleh seorang individu. Fitts berpendapat bahwa konsep diri memiliki pengaruh yang kuat terhadap tingkah laku seseorang. Oleh karena itu, dengan mengetahui konsep diri seseorang maka akan lebih memudahkan untuk meramalkan dan memahami tingkah lakunya. Fitts (dalam Pattimahu, 2015) membagi konsep diri ke dalam dua dimensi besar, yakni dimensi internal dan internal. Di dalam dimensi internal, Fitts membaginya menjadi tiga komponen, yakni identitas diri, perilaku dan penilaian. Ketiga komponen dimensi internal yang diuraikan Fitts memiliki satu kesamaan, bahwa cara seseorang memandang dirinya akan sangat bergantung kepada umpan balik (feedback) yang diberikan oleh lingkungan. Maka dengan konsep diri menjadi sesuatu yang mampu mengontrol tingkah laku, narapidana anak akan memahami konsep dirinya sebagaimana statusnya, yakni seorang anak yang berkonflik dengan hukum (berbuat jahat). Fitts (dalam Oktaviani, 2014) juga menjadikan pengalaman dan kompetensi yang dihargai orang lain menjadi faktor penentu konsep diri individu.

Hal ini sesuai dengan definisi konsep diri yang dikemukakan Papalia (2014) bahwasanya konsep diri hadir sejak masa toddler dan akan semakin jelas gambarannya ketika menghadapi tugas-tugas perkembangan pada masa remaja. Berada di lingkungan yang memiliki kesan negatif bagi masyarakat, sedikit banyaknya akan membawa pengaruh kepada narapidana anak yang secara usia dalam psikologi berada pada usia remaja, yang senantiasa disebut storm phase, meskipun hukum Indonesia sendiri tidak mengenal definisi remaja. Melalui Undang-Undang Nomor 35 Tahun 2014 tentang Perlindungan Anak dan Undang-Undang Nomor 11 Tahun 2012 tentang Pengadilan Anak, pemerintah Republik Indonesia ingin agar narapidana anak diperlakukan sedemikian halnya dengan anak-anak biasa. Keluarga, teman, dan masyarakat umum diharapkan tidak memberikan respon yang negatif kepada anak yang berkonflik dengan hukum demi menghindarkan mereka dari penilaian diri yang buruk akibat refleksi yang diberikan lingkungan, terlebih narapidana kasus narkoba biasanya memiliki penilaian yang lebih buruk dari masyarakat karena mereka dianggap rusak secara fisik dan mental.

Pada akhirnya, untuk membentuk konsep diri yang positif, individu mesti memiliki keyakinan pada dirinya bahwa dirinya adalah seseorang yang positif dan memiliki patokan dalam berperilaku sesuai dengan norma-norma yang berlaku. Mereka hendaknya memiliki kepuasan kepada diri mereka sendiri. Besarnya keyakinan diri individu akan berbanding 
lurus dengan kepercayaan dirinya. Selain itu, individu dengan kritik diri, harga diri dan integrasi diri yang baik akan membawa dirinya sendiri ke arah konsep diri yang positif. Konsep diri merupakan gambaran yang dimiliki seseorang tentang dirinya, yang dibentuk melalui pengalaman, yang diperoleh dari interaksi dengan lingkungan. Lingkungan pertama yang menjadi tempat paling awal bagi individu untuk melakukan kontak sosial adalah keluarga. Dalam keluarga, kelekatan pada orang tua mempunyai peranan yang sangat besar bagi pembentukan dan pengembangan konsep dirinya (Agustiani, 2006).

Gaya kelekatan sendiri diartikan oleh Ainsworth dalam Helmi (1999) sebagai suatu ikatan yang bersifat afeksional pada seseorang yang ditujukan pada orang-orang tertentu atau disebut figur lekat dan berlangsung terus-menerus. Ada tiga jenis gaya kelekatan, yaitu gaya kelekatan secure, resistant dan avoidant. Hasil penelitian Ainsworth membuktikan bahwa setiap gaya kelekatan yang dimiliki individu dapat mempengaruhi kemampuan berhubungan dengan orang lain. Kesadaran pentingnya konsep diri seorang individu dengan gaya kelekatan dapat menarik perhatian peneliti. Hasil penelitian Avin Fadilla Helmi (1999) yang menunjukkan korelasi antara gaya kelekatan dengan konsep diri. Penelitian Ihsana Sabriani Borualogi (2004) yang menunjukkan adanya korelasi antara persepsi tentang figur attachment dengan self-esteem. Begitu pula hasil penelitian Helmi (2004) menunjukkan adanya korelasi antara gaya kelekatan, atribusi, respon emosi, dan perilaku marah.

Berdasarkan gambaran psikologis anak dengan kasus narkoba sebagaimana telah diuraikan di atas, peneliti tertarik untuk mengetahui tentang gambaran konsep diri anak kasus narkoba dengan kelekatan pada ibu.

\section{METODE PENELITIAN}

Metode penelitian yang digunakan dalam penelitian ini adalah deskriptif kualitatif. Subjek dalam penelitian ini adalah anak didik pemasyarakatan dengan kasus narkoba yang berjumlah lima orang di Lembaga Pembinaan Khusus Anak Klas II Pekanbaru. Metode pengumpulan data dengan menggunakan wawancara dan observasi. Teknik validasi data yang digunakan adalah membercheck dan dianalisis dengan metode interaktif. 


\section{HASIL DAN PEMBAHASAN}

Hasil penelitian memberikan gambaran bahwa konsep diri anak dengan kasus narkoba adalah negatif. Dengan konsep diri yang negatif membuat mereka melakukan perilaku yang juga negatif dalam pandangan hukum dan norma-norma yang berlaku di masyarakat. Konsep diri mereka dipengaruhi oleh berbagai macam faktor, dalam penelitian ini ditemukan bahwa faktor lingkungan memiliki peranan besar, yang akhirnya menyebabkan mereka berkonflik dengan hukum. Mereka tidak memiliki suatu konsep diri yang benar-benar mampu membawa mereka berperilaku sesuai dengan yang diinginkan norma-norma yang ada, dan salah satunya adalah norma hukum.

Banyak faktor yang menyebabkan para subjek terlibat dalam peredaran narkoba, baik sebagai pemakai maupun penjual/kurir. Berdasarkan hasil penelitian menunjukkan bahwa faktor terkuat yang berperan dalam perilaku mereka adalah faktor lingkungan. Semua subjek mengatakan bahwa teman bermain mereka adalah anak-anak yang terlibat dalam peredaran narkoba. Pada subjek kedua dan kelima, mereka tinggal di daerah Kampung Dalam, yang oleh masyarakat Kota Pekanbaru dan kepolisian sudah dianggap sebagai sarang narkoba. (Tribun, diakses tanggal 27 Mei 2017). Fitts (dalam Pattimahu, 2005) menjelaskan salah satu sebab perilaku timbul adalah adanya umpan balik (feedback) dari lingkungan. Ketika seseorang mengatakan bahwa narkoba bukanlah sesuatu yang haram, dan seseorang tersebut sangat berarti bagi subjek, maka subjek ini akan terpengaruh oleh ucapan tersebut dan mempengaruhi kelanjutan dari tingkah lakunya. Subjek diberikan gambaran bahwa yang salah dalam narkoba adalah hanya penyalahgunaan atau penggunaan yang berlebihan sedangkan narkoba memiliki manfaat tersendiri, maka subjek menjadikan hal tersebut sebagai alasan ia menggunakan narkoba atau menjual narkoba.

Keadaan lingkungan tempat tinggal yang marak dengan peredaran narkoba memberi andil yang besar kepada subjek dalam pembentukan konsep diri. Subjek terbiasa bermain, berkumpul dan bercengkrama dengan para pecandu narkoba, apalagi bandar narkoba, sehingga lama kelamaan subjek ikut menjadi pemakai, atau menjadi agen penjual narkoba. Apalagi jika melihat bahwa uang yang didapat dari menjual narkoba cukup besar untuk usia anak di bawah umur yang sesuai dengan penelitian ini. Konformitas akan terbentuk seiring interaksi subjek dengan lingkungan yang marak dengan peredaran narkoba. 
Anak didik pemasyarakatan dengan kasus narkoba memiliki gaya kelekatan pada ibu yang kurang aman, artinya relasi afeksional antara anak dan ibu kurang mendalam. Berdasarkan kualitas hubungan anak dengan ibu sebagai pengasuh, maka anak akan mengembangkan konstruksi mental atau internal working model mengenai diri dan orang lain yang akan akan menjadi mekanisme penilaian terhadap penerimaan lingkungan (Bowlby dalam Pramana 1996). Anak yang merasa yakin terhadap penerimaan lingkungan akan mengembangkan kelekatan yang aman dengan figur lekatnya (secure attachment) dan mengembangkan rasa percaya tidak saja pada ibu juga pada lingkungan. Hal ini akan membawa pengaruh positif dalam proses perkembangannya. Beberapa penelitian membuktikan bahwa anak yang memiliki kelekatan aman akan menunjukkan kompetensi sosial yang baik pada masa kanak-kanak (Both dkk dalam Parker, Rubin, Price dan DeRosier, 1995) serta lebih populer dikalangan teman sebayanya di prasekolah (La Freniere dan Sroufe dalam Parker, Rubin, Price dan DeRosier, 1995). Anak-anak ini juga lebih mampu membina hubungan persahabatan yang intens, interaksi yang harmonis, lebih responsif dan tidak mendominasi (Parke dan Waters dalam Parker, Rubin, Price dan DeRosier,1995). Sementara itu Grosman dan Grosman (dalam Sutcliffe, 2002) menemukan bahwa anak dengan kulitas kelekatan aman lebih mampu menangani tugas yang sulit dan tidak cepat berputus asa.

Sebaliknya pengasuh yang tidak menyenangkan akan membuat anak tidak percaya dan mengembangkan kelekatan yang tidak aman (insecure attachment). Kelekatan yang tidak aman dapat membuat anak mengalami berbagai permasalahan yang disebut dengan gangguan kelekatan (attachment disorder). Telah disebutkan di atas bahwa gangguan kelekatan terjadi karena anak gagal membentuk kelekatan yang aman dengan figur lekatnya. Hal ini akan membuat anak mengalami masalah dalam hubungan social. Beberapa penelitian menunjukkan bahwa anak yang mengalami gangguan kelekatan memiliki orang tua yang juga mengalami masalah yang sama dimasa kecilnya (Sroufe dalam Cicchetty dan Linch, 1995). Hal ini menjadi sebuah lingkaran yang tidak akan terputus bila tidak dilakukan perubahan.

\section{E. SIMPULAN}

Berdasarkan hasil penelitian dapat disimpulkan bahwa konsep diri anak didik pemasyarakatan dengan kasus narkoba di Lembaga Pembinaan Khusus Anak kelas II Pekanbaru negatif, sehingga memunculkan perilaku yang negatif berdasarkan norma- 
norma yang berlaku. Sedangkan gambaran kelekatan pada ibu termasuk kurang aman, artinya kualitas hubungan afeksi antara anak didik pemasyarakatan pada ibu kurang mendalam. 


\section{DAFTAR REFERENSI}

Agustiani, H. (2006). Psikologi Perkembangan. Bandung: Refika Aditama.

Andayani,T.R., (2001). Perlakuan Salah Terhadap Anak (Chil Abuse) Ditinjau dari Nilai Anak dan Tingkat Pendidikan Orang Tua. Tesis. Yogyakarta: Program Studi Psikologi Pascasarjana Universitas Gadjah Mada

Baron, Robert, Donn Byrne. (2005). Psikologi Sosial. Jakarta: Erlangga

Bee, H. (1981). The Developing Child. Third edition. New York. Harper International.

Burns, R. B. (1979). Konsep Diri. Jakarta: Arcan.

Cicchetti, D \& Toth, S.L., (1995). Developmental Psychopatology and Disorder of Affect.. John Willey and Sons Inc

Creswell, John. (2009). Research Design: Pendekatan Kualitatif, Kuantitatif dan Mixed. Yogyakarta: Pustaka Pelajar.

Herdiansyah, Haris. (2015). Metodologi Penelitian Kualitatif untuk Ilmu Psikologi. Jakarta: Salemba Humanika.

Idrus, Muhammad. (2009). Metode Penelitian Ilmu Sosial: Pendekatan Kualitatif dan Kuantitatif. Jakarta: Erlangga.

Maentiningsih, Desiani. (2008). Hubungan antara Secure Attachment dengan Motivasi Berprestasi pada Remaja. Jurnal Fakultas Psikologi Universitas Gunadarma.

Moeloeng, Lexy J. (2013). Metodologi Penelitian Kualitatif. Bandung: Rosda.

Oktaviani, Chiktia Irma. (2014). Konsep Diri Remaja Dari Keluarga Broken Home. Jurnal Fakultas Psikologi Universitas Islam Negeri Maulana Malik Ibrahim Malang.

Papalia, Diane E, Ruth Duskin Feldman. (2014). Menyelami Perkembangan Manusia. Jakarta: Salemba Humanika.

Papalia, Diane, dkk. (2008). Psikologi Perkembangan. Jakarta: Kencana Prenada Media Group.

Pardede, Yudit Oktaria Kristiani. (2008). Konsep Diri Anak Jalanan Usia Remaja. Jurnal Psikologi Universitas Gunadarma. Vol. 1. No. 2.

Parker, J.G., Rubin, K.H., Price, J.M., DeRosier, E.M., (1995). Child Development and Adjustment: A developmental Psychology Perspective. John Willey and Sons Inc 
Pattimahu, Indra Kamara. (2005). Perbedaan Konsep Diri Antara Remaja yang Sejak Masa Akhir Kanak-kanaknya Dibesarkan di Panti Asuhan dengan Remaja yang Sejak Masa Akhir Kanak-kanaknya Dibesarkan di Rumah Bersama Keluarga. Jurnal Fakultas Psikologi Universitas Gunadarma Jakarta.

Pramana, W, (1996). The Utility of Theories of Parenting, Attachment, Stress and Stigma in Predicting Adjustment to Illness. Desertasi. Departement of Psychology the University Of Queensland.

Shavelson, Richard J., Roger Bolus. (1981). Self Concept: The Interplay of Theory and Methods. Jurnal Edukasi Psikologi Santa Monica, California. Vol. 74, No. 1.

Shofiah, Vivik, dkk. (2014). Psikologi Pendidikan. Pekanbaru: Al-Mujtahadah Press

Stewart, Charles J. William B. Cash, Jr. (2012). Interviu: Prinsip dan Praktik. Jakarta: Salemba Humanika.

Sugiyono. (2013). Metode Penelitian Kuantitatif, Kualitatif dan ReDD. Bandung: Alfabeta.

Sumarlin, Rahayu. (2009). Perilaku Konformitas pada Remaja yang Berada di Lingkungan Peminum Alkohol. Jurnal Fakultas Psikologi Universitas Gunadarma.

Sutataminingsih, Raras. (2009). Konsep Diri. Fakultas Psikologi Universitas Sumatera Utara.

Sutcliffe, J., (2002). Baby Bonding, Membentuk Ikatan Batin dengan Bayi. Jakarta: Taramedia \& Restu Agung

Ulfie, Agustinus. (2013). Kearifan Lokal Budaya Ain Ni Ain Masyarakat Kei sebagai Sumber Belajar Sejarah Lokal untuk Memperkokoh Kohesi Sosial Siswa. Universitas Pendidikan Indonesia.

Verawati, Yully. (2013). Studi Deskriptif Eksploratif Penyesuaian Diri Pada Narapidana di Lembaga Pemasyarakatan Kelas Ii.A Pekanbaru Riau. Skripsi Fakultas Psikologi Universitas Islam Negeri Sultan Syarif Kasim Riau.

Yuliza, Emmi. (2013). Pembinaan Terhadap Narapidana Anak Pelaku Tindak Pidana Pelecehan Seksual. Jurnal Ilmiah Fakultas Ilmu Hukum Universitas Taman Siswa Padang.

Zimmerman, Barry J. (2000). Self Efficacy: An Essential Motive to Learn. Journal Contemporary Educational Psychology 25. 